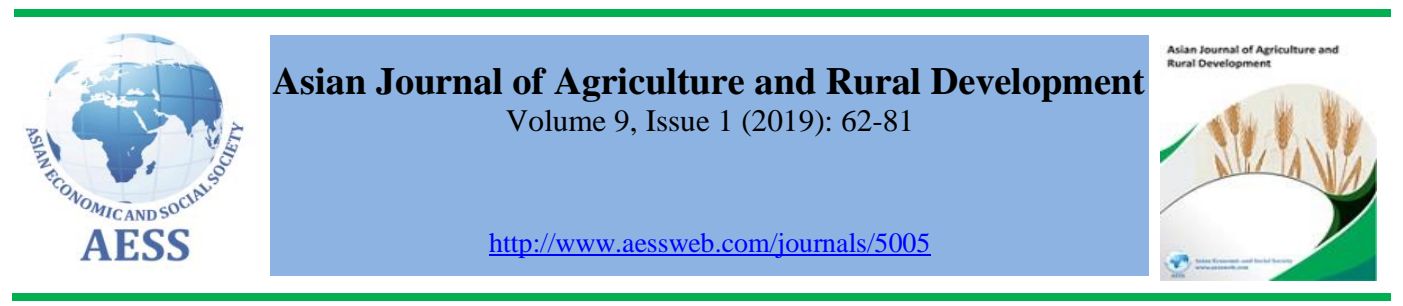

\title{
EXPLORING OPTIMAL CEREAL CROP SEQUENCE USING CULTIVATED LAND UTILIZATION INDEX AND YIELD IN KATIHAR DISTRICT, INDIA: A SUB DIVISION LEVEL ANALYSIS
}

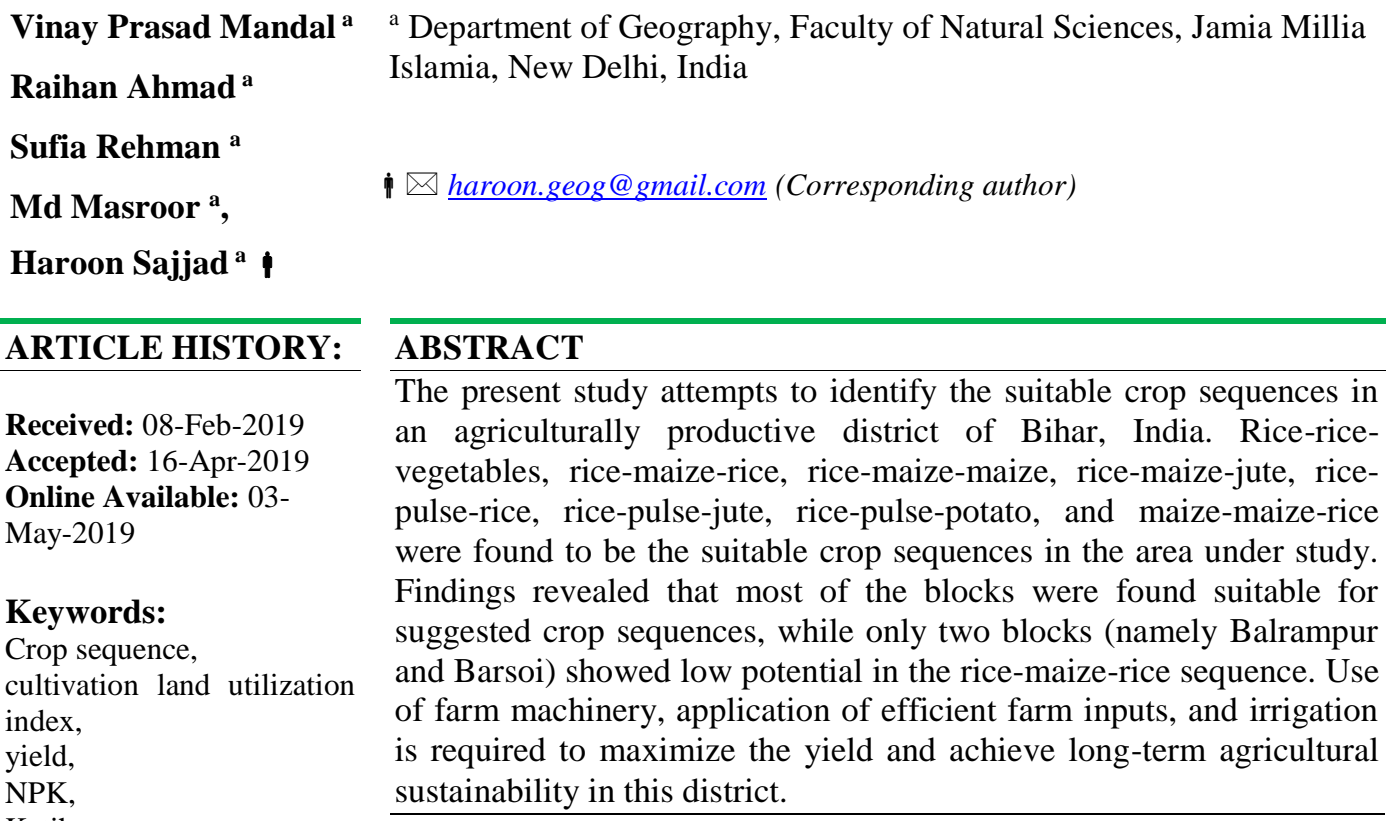

Katihar

\begin{abstract}
Contribution/ Originality
This study intends to identify the suitable cropping sequence for achieving a long-term sustainability in agriculture, in the Katihar district of Bihar, India. This study tried to establish the relationship of yield with cultivated land utilization index (CLUI), soil bulk density, and NPK, for suggesting suitable crop sequence for sustainable agricultural development in the district.
\end{abstract}

DOI: 10.18488/journal.1005/2019.9.1/1005.1.62.81

ISSN (P): 2304-1455/ISSN (E):2224-4433

How to cite: Vinay Prasad Mandal, Raihan Ahmad, Sufia Rehman, Md Masroor and Haroon Sajjad (2019). Exploring optimal cereal crop sequence using cultivated land utilization index and yield in Katihar district, India: a sub division level analysis. Asian Journal of Agriculture and Rural Development, 9(1), 62-81.

(C) 2019 Asian Economic and Social Society. All rights reserved. 


\section{INTRODUCTION}

Agriculture has always been an important source of livelihood to the rural masses in India. Increasing population pressure on resources has been a barrier to achieving agricultural sustainability, especially in rural areas. Identification of suitable crop sequence and efficacious measures to increase agricultural yield, is necessary for sustainable agricultural development. Agriculture has gone through many stages over time. It does not only provide livelihood, but also plays a key role in the manufacturing and industrial sectors (Sajjad et al., 2014). Agriculture has made rapid strides over the years, and many countries like Russia federation, India, China, Brazil and Indonesia, have started participating in international agricultural markets. Export of agricultural commodities in these nations have increased from $9.4 \%$ to $20 \%$ between 2000 and 2015. A similar pattern was also observed in imports (FAO, 2018). However, at the same time agriculture has also been affected by urbanization, industrialization and climate change. The reducing level of GHGs, has also increased conflict for land and water resources (FAO, 2017). Nearly $33 \%$ farms in dry lands have been highly degraded affecting overall livelihood, health of the ecosystem, food security and impoverishment of farming communities, globally (FAO, 2014). Hence, achieving agricultural sustainability with less resource intensification is a great challenge, particularly for developing countries like India. Fulfilling the demand of 10 billion people for fibre, fuel and food by 2050 is a difficult task. For achieving long-term sustainability in agricultural production, it must be grown at an average rate of $1.75 \%$ by 2050 (Global Agricultural Productivity Index, 2018). It is also anticipated that food demands would reach $60 \%$ by 2050 . Therefore, effectual farming practices are essential to make production sustainable (Liebisch et al., 2014).

Characterization of farming system refers to the assessment of nature and traits of farming system, in terms of inputs like irrigation, fertilizers, high yielding variety of seeds, insecticides, pesticides, land use and quality of soils, etc. It is also essential to assess the cropping pattern, crop combination, crop intensity, crop diversification, utilization of cultivated land and yield, when suggesting long term sustainability of agricultural systems. Characterization of a farming system is significant, especially in a diversified farming system. Adoption of new techniques play an important role in achieving such characterization (Timler et al., 2014). Indian agriculture has experienced tremendous changes in the previous century. Increase in food production exceeded the population growth since in the 1960s (Sajjad et al., 2014). Earlier, the emphasis were laid on ensuring self-sufficiency in production, which was somehow achieved. This massive production resulted to various socio-environmental implications, ranging from social lamentation to degrading land and natural resources (Abrol and Sangar, 2006). The size of most of the landholdings in India are small, resulting to meagre income of the farmers. Of the total landholdings, nearly $86 \%$ of the farmers belong to the small and marginal farmers' category (Iqbal, 2018). Characterization of farming system requires assessment of land use/land cover modification. Land cover transformation affects fallow cycles, cropping pattern, crop rotation, etc. The main features of land cover modification are increasing land use production and intensification of land use. This land intensification has direct impact on cropping intensity which simultaneously helps in understanding the relationship between natural resources, people and sustainable land resource management (Zhang and Li, 2016). Agricultural sustainability at farm level can be helpful in creating a holistic perspective of ecological, social and economic development (Sajjad and Nasreen, 2016).

Cropping pattern, cropping system and cropping intensity are significant parameters of farming system characterization, determined by the climate, soil, nourishment and other farm level components (Das, 2006). Land holdings and regional characteristics, determine the cropping pattern as monoculture, mixed cropping, double cropping and sequential cropping. Farmers with less land holdings are vulnerable to climate change, fragmentation of land, and lesser earnings. Diversified mixed cropping can significantly minimize the vulnerability of farmers, by improving 
the crop yield and derived benefits (Amejo et al., 2019). Cropping intensity is mainly defined as the ratio of output and input in an agricultural system (Ruiz-Martinez et al., 2015). Assessment of cropping intensity will also help in attaining agricultural productivity, while maintaining the sustainability of the environment (Fan et al., 2014). It is generally believed that agriculture may lead to environmental problems, which is not usually the case. Prudent agricultural activities can significantly provide solutions to various environmental problems, but monitoring has several implications. However, agricultural monitoring is more difficult than other economic sectors (Dumanski and Pieri, 2000). Various scholars have examined agricultural intensity in terms of single components like micronutrients (Kleijn et al., 2008; Overmars et al., 2014) and pesticides (Ruiz-Martinez et al., 2015). Several consensuses among scientific studies were made to characterize the farming system (Hess and Hoskinson, 1996; Van et al., 2010; Alemu, 2016). Bembridge (1987) analysed the various constraints of a farming system namely, unscrupulous inputs, technological barriers and small landholdings. Knowledge of crops with adequate technological support were identified as the two important determinants of a crop farming system.

Remote sensing data is playing an important role in identifying the cropping types, cropping intensity and plant phenology at various scales (Fan et al., 2014). Geospatial techniques have emanated as significant tools to prepare spatial inventory of cropping pattern, land use characteristics, examining the biophysical characters and land resources (Choudhury et al., 2006). Various indices obtained from high resolution satellite data as leaf area index (LAI), leaf water content (LWC), canopy cover (CC), plant chlorophyll content and normalized difference vegetation index (NDVI), etc. can help in identifying inherent cropping characteristics (Liebisch et al., 2014). Chatterjee et al. (2015) characterized the farming system and farm typology, using multivariate statistical, cluster and principal component analyses. They emphasized that identification of farm typology may significantly reduce the problems of farmers and can be indelible to provide better livelihood opportunities. Assessment of soil and land use characteristics are indispensable for increasing the productivity. NDVI and assessment of ground cover derived from satellite data, provides empirical information regarding the land and soil quality (Sheffield and Morse-McNabb, 2015). Land suitability is carried out when assessing the sustainability of agriculture. It is focused on the assessment of the potentiality of land, for specific utilization (Jamil et al., 2018a). Zhang and Li (2016) examined the agrarian land use intensity of varied characteristics using principal component and energy analyses in Beijing, China. Jamil et al. (2018b) examined the cropland suitability through GIS based multi-criteria decision-making, using site-specific parameters in the Bijnor district of Uttar Pradesh, India. Singh et al. (2013) characterized the farming system in southern arid lands of Rajasthan, using field derived samples. They identified that lack of farming techniques and planting methods hindered the farming efficiency. Sajjad et al. (2014) examined the spatial and temporal variability of agricultural sustainability in the Vaishali district, using sustainable livelihood security index (SLSI) at block level. Bio-intensive farming requires appropriate cropping pattern, techniques and agricultural inputs in order to maintain the output sustainability. Sajjad and Prasad (2014) evaluated the crop diversification in the Jalandhar district of Punjab, India using the Gibs and Martin index. They identified that, declining crop diversification may affect farmers' income, nutrients, natural resources and ground water, etc. Rajbhandari (2011) evaluated the efficiency and relationship among land utilization index (LUI), rotational intensity and yield efficiency for analysing the biointensive farming system.

Katihar is a district of Bihar in India, known for its agricultural productivity and yield. Agriculture is the mainstay of the economy, and provides livelihood to the rural masses. Analysis of present cropping pattern, is essential in suggesting alternate crop-based farming systems. Thus, this study intends to characterize crop farming, based on the land utilization index. This study also tried to examine the relationship between cultivated land utilization index (CLUI), soil bulk density, NPK and yield, in suggesting a suitable crop sequence for sustainable agricultural development. 


\subsection{Study area}

Katihar is a district in Bihar, India covers an area of $3057 \mathrm{~km}^{2}$ lies between $25^{\circ} 13^{\prime}$ to $25^{\circ} 53^{\prime}$ north latitudes and $87^{\circ} 12^{\prime}$ to $87^{\circ} 04^{\prime}$ east longitudes (Figure 1). The district comprises 16 blocks (administrative division of the district). It relishes a warm temperate climate with three distinct seasons winter, summer and rainy seasons. Average temperature and rainfall of the district is $24{ }^{\circ} \mathrm{C}$ and $1281 \mathrm{~mm}$. Monsoon showers take place during June to September which leads to increase in water level up to 50 times higher causing devastating floods. Numerous tributaries of Kosi and Mahananda Rivers flow across the study area. Major soils in the district are Haplic Fluvisols, Stagnic Cambisols, Fluvic Cambisols, Haplic Cambisols, Endogleyic Cambisols and Haplic Arenosols (Reza et al., 2017). Nearly 2.41 lakhs people reside in the district. Agricultural population comprises nearly 11279 and marginal workers around 13049 (Census, 2011). Agriculture is the major source of livelihood to the rural masses as this district lies in Mid Gangetic plane region of agro-climate zone. Of the total area of district (291 ha) nearly 146 ha are cultivable and 39 hac are non-agricultural lands while 10 ha came under miscellaneous tree crops and groves, 22 ha under barren and uncultivable and 1.7 ha area came under forest (Agriculture Contingency Plan for District, 2012). Katihar is one of the agriculturally advanced districts of Bihar in India. The farmers grow crop during all the three seasons (Rabi, Kharif and Zaid).

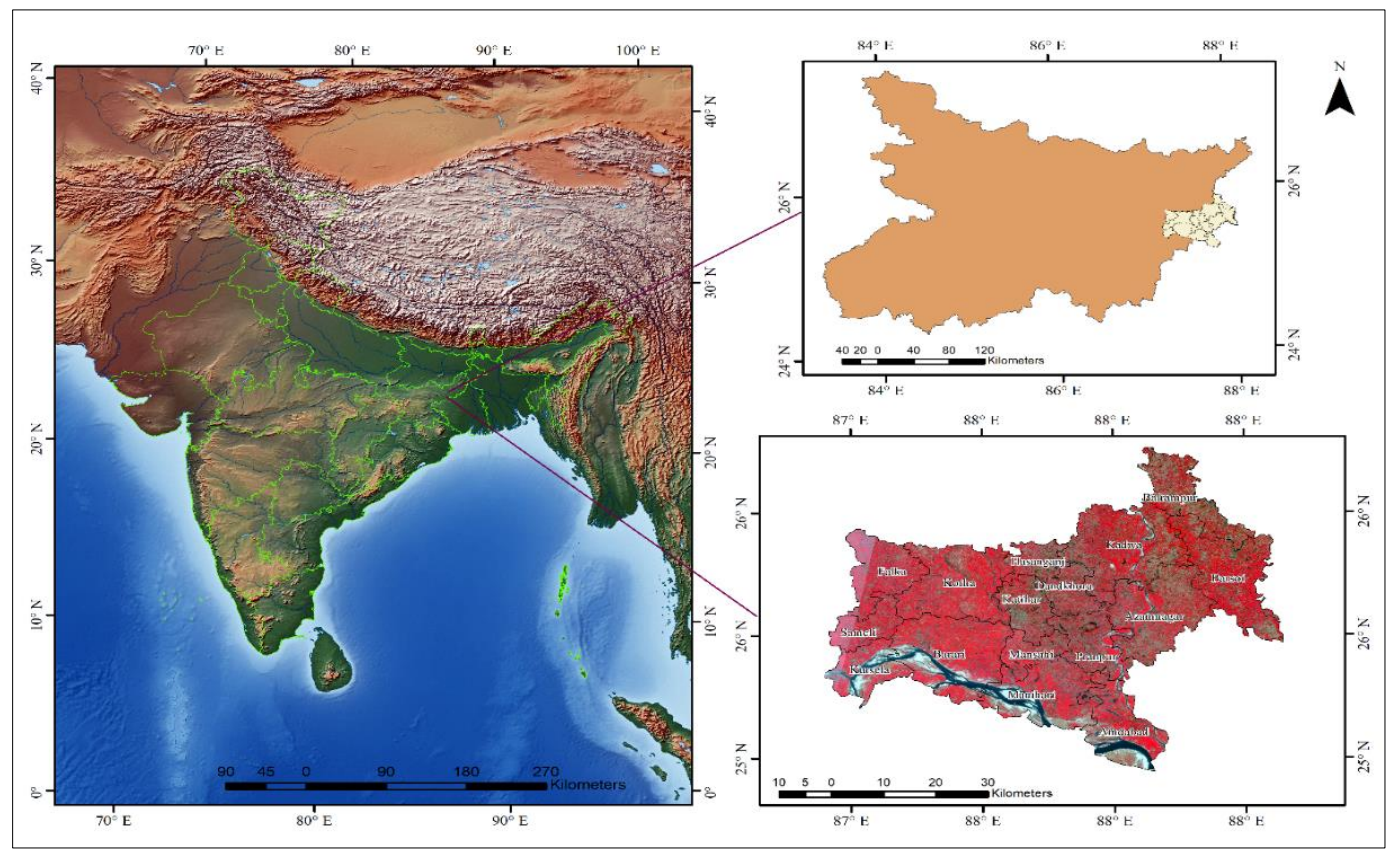

Figure 1: Location map of the study area

\section{METHODOLOGY}

For identifying the land use under agriculture, land use/land cover map was prepared from Sentinel 2A data through supervised classification. Cropping pattern was identified using Sentinel 2A data and verified with GPS locations. Maps of cropping pattern in kharif (rainy season crop), rabi (winter season crop) and Zaid (short season between kharif and rabi seasons) seasons were used to examine the crop sequence in the study area.

Cultivated land utilization index (CLUI) is essential for assessing the utilization of efficiency and designates where the land is being utilized. It is generally represented in percentage or fraction. If the value of CLUI is 1 it shows that the land is fallow if it is more than 1 then it represents the 
relay and intercropping (Rana and Rana, 2011). CLUI assists in identifying the cropping sequence and to increase the land productivity for agriculture (Panigrahy et al., 2005). Block wise CLUI was calculated to identify the land utilization in kharif, rabi and Zaid seasons as:

$$
C L U I=\frac{a_{1} b_{2}}{A \times 365} \times 100
$$

Where, $a 1$ refers to area occupied by $\mathrm{i}^{\text {th }}$ crop, 1,2 is the total number of crops, $\mathrm{A}$ is the total cultivated land area available for 365 days.

Relationship of yield with soil bulk density, nitrogen, phosphorus and potassium (NPK) and irrigation was determined to distinguish the suitable cropping sequence in the study area. The detailed methodology is presented in Figure 2.

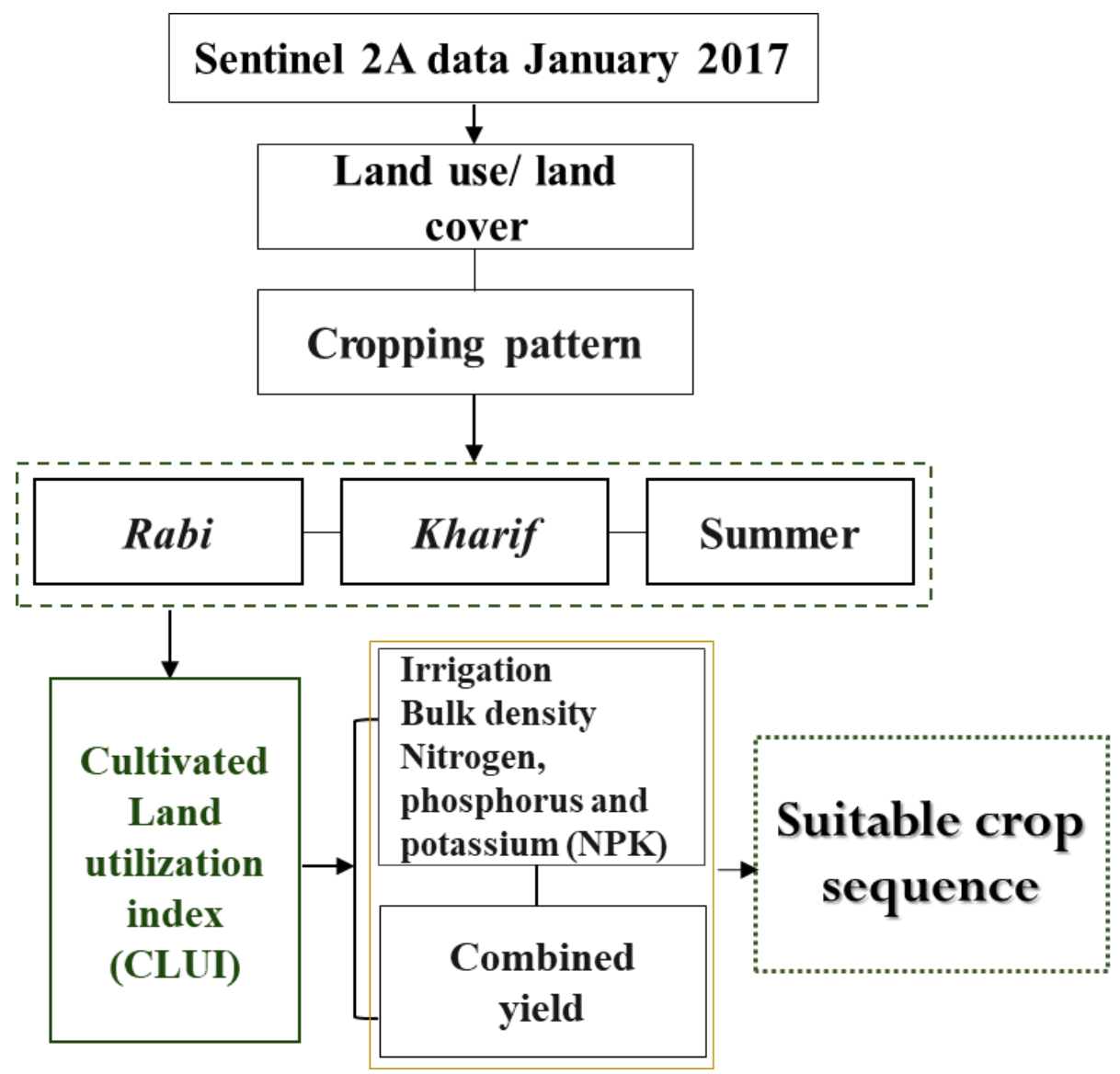

Figure 2: Methodological framework of the study

\section{RESULTS AND DISCUSSION}

Of the total geographical area (183160 hectares), nearly $60 \%$ is under agriculture including fallow land (Table 1 and Figure 3). Not all the area under agriculture is utilized in all the seasons because of low rainfall and non-availability of irrigation. Nearly 133939 ha is utilized for agriculture during Kharif season, 119910 ha during Rabi season and 128574 ha in Zaid season. Largest area under agriculture is utilized during Kharif season mainly due to monsoon rainfall. 
Table 1: Block wise area under various classes of land use/land cover in Katihar district (2017)

\begin{tabular}{|c|c|c|c|c|c|c|c|}
\hline \multirow[t]{2}{*}{ Block } & \multicolumn{7}{|c|}{ Area in $\mathbf{H a}$} \\
\hline & Agricultural \& fallow land & Built-up Land & Plant/Forest & Scrub and Grass & Wetlands & Rivers & Total \\
\hline Azamnagar & 16460 & 3170 & 3600 & 2630 & 1230 & 1420 & 28500 \\
\hline Amdabad & 10420 & 3100 & 1440 & 1040 & 490 & 3700 & 20200 \\
\hline Barari & 20940 & 3560 & 2280 & 1430 & 750 & 3890 & 32900 \\
\hline Balrampur & 9500 & 2700 & 2090 & 1550 & 720 & 1120 & 17700 \\
\hline Barsoi & 19200 & 2350 & 2860 & 1790 & 950 & 1000 & 28200 \\
\hline Dandkhora & 4600 & 1210 & 1280 & 1000 & 450 & 520 & 9100 \\
\hline Falka & 11440 & 580 & 2450 & 1490 & 810 & 150 & 16900 \\
\hline Hasangunj & 3890 & 930 & 850 & 680 & 290 & 400 & 7100 \\
\hline Kadwa & 20960 & 3350 & 3990 & 2560 & 1340 & 1650 & 33900 \\
\hline Katihar & 5890 & 1710 & 1300 & 1080 & 460 & 610 & 11000 \\
\hline Korha & 21980 & 1160 & 3210 & 1930 & 1060 & 580 & 29900 \\
\hline Kursela & 6520 & 2360 & 800 & 530 & 260 & 2310 & 12800 \\
\hline Manihari & 12020 & 4340 & 2050 & 1330 & 690 & 4310 & 24700 \\
\hline Mansahi & 5040 & 640 & 900 & 620 & 300 & 420 & 7900 \\
\hline Pranpur & 7690 & 1950 & 1930 & 1370 & 670 & 1740 & 15300 \\
\hline Sameli & 6610 & 370 & 1280 & 810 & 430 & 150 & 9600 \\
\hline Total & 183160 & 33480 & 32310 & 21840 & 10900 & 23970 & 305700 \\
\hline
\end{tabular}

Source: Authors' own calculations based on Sentinel 2A data (January, 2017) 


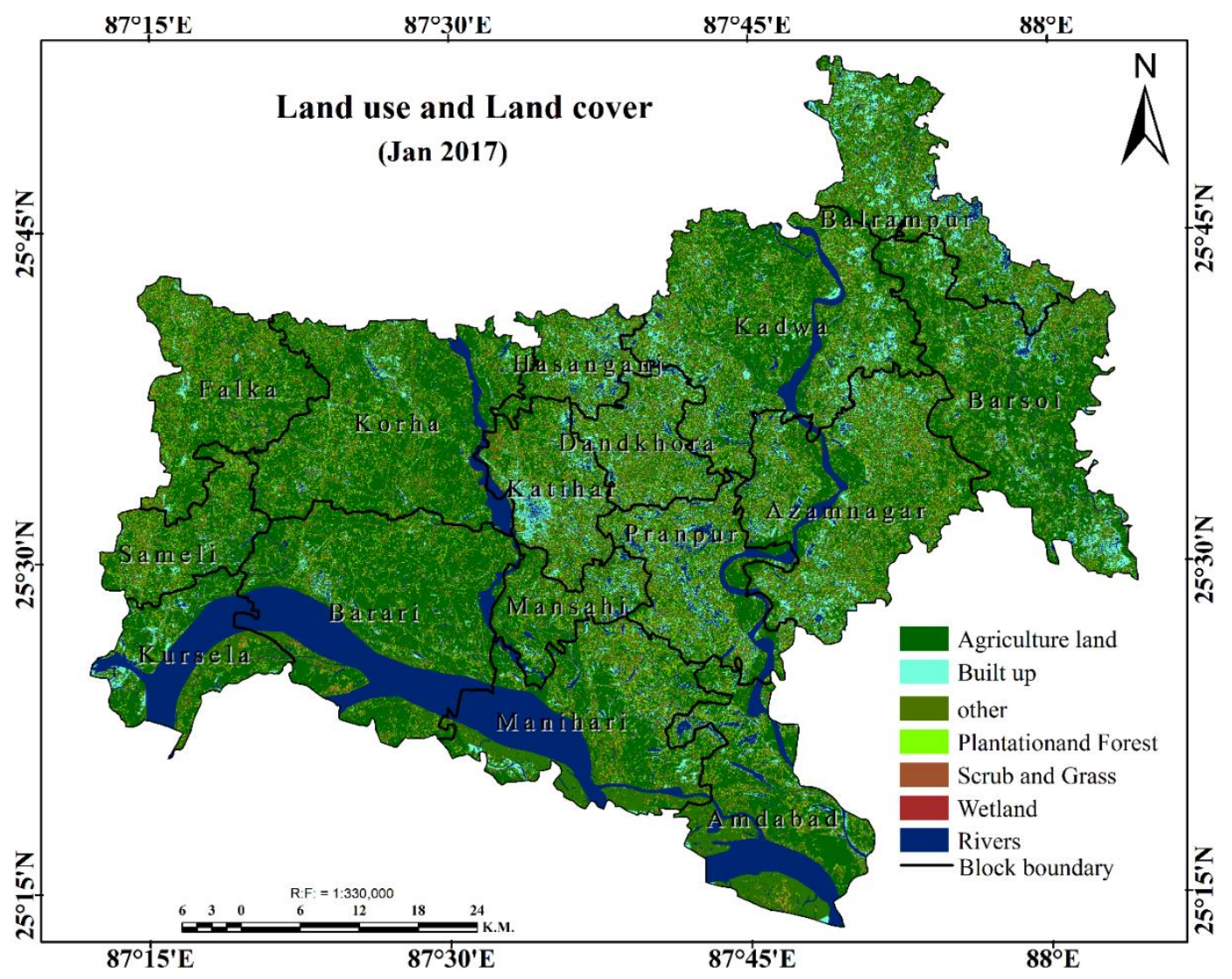

Figure 3: Land use/land cover of Katihar district (2017)

Major crops in the kharif season are rice, maize, pulses and vegetables (Figure 4A). Wheat, rice, maize, mustard, pulses, banana and vegetables are the dominant crops in rabi season in the study area while rice, maize, jute and pulses are important crops in the Zaid season (Figure 4B \& C). Crop land utilization index (CLUI) is a measure to understand the availability of agricultural land for whole year. However, it also determines the land occupancy for crop during a particular season. Therefore, CLUI was calculated for both seasonal and annual cultivation practices (Table 2). For Kharif season high CLUI was found in Sameli, Pranpur, Mansahi, Korha, Katihar, Kadwa, Hasangunj, Dandkhora, Azamnagar and Balrampur blocks of the district. Falka, Amdabad, Manihari, Barari and Kursela blocks have recorded moderate CLUI while low CLUI was found in Barsoi. In Rabi season high CLUI was observed in Amdabad, Manihari and Pranpur blocks of Katihar district. Moderate CLUI was found in Barari, Kadwa, Mansahi, Kursela, Korha, Dandkhora and Hasangunj blocks while Falka, Sameli, Azamnagar, Balrampur, Katihar and Barsoi blocks have experienced low CLUI in Rabi season. High CLUI in Zaid season was found in Pranpur, Balrampur, Azamnagar, Dandkhora, Hasangunj, Kadwa, Amdabad, Katihar and Barsoi blocks of the districts. Moderate CLUI was observed in Mansahi, Manihari, Falka, Sameli and Korha blocks while low CLUI was found in Barari and Kursela blocks. High annual CLUI was found in Pranpur, Amdabad, Dandkhora, Kadwa. 
Table 2: Block wise cultivated land utilization index during different seasons in Katihar district

\begin{tabular}{|c|c|c|c|c|c|c|c|c|}
\hline \multirow{2}{*}{ Blocks } & \multicolumn{2}{|c|}{ Kharif } & \multicolumn{2}{|c|}{ Rabi } & \multicolumn{2}{|c|}{ Zaid } & \multicolumn{2}{|c|}{ Annual } \\
\hline & Net shown & CLUI & Net shown & CLUI & Net shown & CLUI & CLUI & Crop Intensity \\
\hline Azamnagar & 14297.50 & 0.26 & 8448.00 & 0.14 & 15432.00 & 0.30 & 0.73 & 245.08 \\
\hline Amdabad & 5873.00 & 0.17 & 8584.00 & 0.22 & 8506.00 & 0.26 & 0.78 & 264.01 \\
\hline Barari & 15476.50 & 0.22 & 15958.00 & 0.20 & 7141.00 & 0.11 & 0.62 & 210.31 \\
\hline Balrampur & 9474.90 & 0.30 & 4934.00 & 0.14 & 9302.00 & 0.31 & 0.74 & 249.85 \\
\hline Barsoi & 2250.80 & 0.04 & 8977.00 & 0.13 & 14499.00 & 0.24 & 0.66 & 222.27 \\
\hline Dandkhora & 4434.60 & 0.29 & 2887.00 & 0.17 & 4348.00 & 0.30 & 0.76 & 257.28 \\
\hline Falka & 5181.60 & 0.14 & 6666.00 & 0.16 & 7226.00 & 0.20 & 0.66 & 221.43 \\
\hline Hasangunj & 3863.50 & 0.30 & 2531.00 & 0.17 & 3244.00 & 0.27 & 0.74 & 248.46 \\
\hline Kadwa & 17575.40 & 0.25 & 15235.00 & 0.20 & 17448.00 & 0.27 & 0.76 & 255.93 \\
\hline Katihar & 5830.00 & 0.30 & 3052.00 & 0.14 & 4515.00 & 0.25 & 0.68 & 228.47 \\
\hline Korha & 19707.50 & 0.27 & 15133.00 & 0.18 & 12039.00 & 0.18 & 0.66 & 223.62 \\
\hline Kursela & 4448.20 & 0.21 & 4654.00 & 0.19 & 1736.00 & 0.09 & 0.59 & 198.01 \\
\hline Manihari & 8656.40 & 0.22 & 9463.00 & 0.21 & 7851.00 & 0.21 & 0.72 & 244.04 \\
\hline Mansahi & 4575.10 & 0.27 & 3719.00 & 0.20 & 3534.00 & 0.22 & 0.72 & 243.91 \\
\hline Pranpur & 7112.40 & 0.28 & 6058.00 & 0.21 & 7666.00 & 0.32 & 0.82 & 278.47 \\
\hline Sameli & 5181.60 & 0.24 & 3611.00 & 0.15 & 4087.00 & 0.20 & 0.64 & 216.46 \\
\hline Total & 133939.00 & 0.22 & 119910.00 & 0.18 & 128574.00 & 0.23 & 0.70 & 235.66 \\
\hline
\end{tabular}

Source: Authors' own calculations based on Sentinel 2A data (January, 2017) 
Balrampur and Hasangunj blocks. Moderate annual CLUI was found in Azamnagar, Manihari, Mansahi and Katihar blocks whereas Barsoi, Falka, Korha, Sameli, Barari and Kursela blocks have experienced low annual CLUI. From the above results it is very clear that CLUI in Katihar district is not homogeneous due to rainfall availability and irrigation potential. The farmers are bound to carry out their agricultural practices influenced by rainfall, flood, irrigation potential and land quality. Various crops are grown during kharif season in the district specially rice, maize, pulses and vegetables. Number of crops grown are more during rabi season than kharif due to variation in topography and flood which includes wheat, rice, maize, mustard, pulses and vegetables. Rice, maize, Jute, pulses and vegetables are dominant crops during Zaid season.

Crop sequence in a year was identified to suggest a suitable crop farming system in Katihar district. Maps of cropping pattern during different seasons were prepared using remote sensing data. Based on those thematic maps, crop sequence was identified and area occupied by those crop sequences was determined. Crop yield data of all blocks were used to identify the suitable crop sequences (Table 3). The combined average yield for three seasons of $150 \mathrm{q} / \mathrm{ha}$ was used as a lower margin for selection of crop sequences. In this way eight sequences were suggested for sustainable farming system. These sequences are rice-rice-vegetables, rice-maize-rice, rice-maizemaize, rice-maize-jute, rice-pulse-rice, rice-pulse-jute, rice-pulse-potato and maize-maize-rice. Yield and CLUI for these sequences were also calculated for every block in the district (Table 4 and Table 5). 

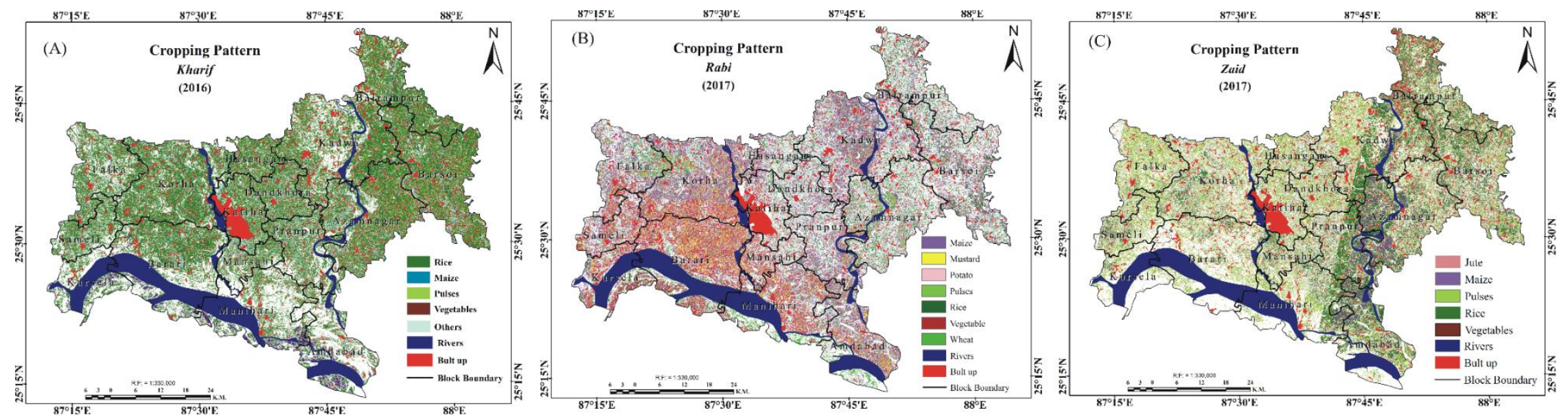

Figure 4: Cropping pattern in Katihar district: A) Kharif (during 2016), B) Rabi (during 2017) and C) Zaid (during 2017)

Table 3: Yield of crops during Rabi, Kharif and Zaid seasons in the study area

\begin{tabular}{|c|c|c|c|c|c|c|c|c|c|c|c|c|c|c|c|c|}
\hline \multirow{2}{*}{ Blocks } & \multicolumn{5}{|c|}{ Kharif Yields (Q/ha) } & \multicolumn{5}{|c|}{ Rabi crop Yields (Q/ha) } & \multirow[b]{2}{*}{ Potato } & \multicolumn{5}{|c|}{ Zaid Crop Yields (Q/ha) } \\
\hline & Rice & Maize & Pulses & egetable: & sWheat & Rice & Maize & Mustard & Pulses & Vegetable & & Rice & Maize & Jute & Pulses & Vegetables \\
\hline Azamnagar & 32.67 & 92.86 & 7.72 & 150.52 & 28.89 & 47.65 & 133.45 & 12.35 & 8.47 & 188.1543 & 262.1055 & 24.7128 & 62.860 & 30.99286 & 8.09381 & 123.5235 \\
\hline Amdabad & 25.57 & 0.00 & 8.92 & 144.68 & 25.32 & 40.54 & 137.57 & 14.27 & 9.67 & 180.8528 & 284.5717 & 26.2106 & 0.000 & 36.40361 & 9.29620 & 117.6823 \\
\hline Barari & 22.64 & 84.73 & 6.05 & 135.33 & 21.33 & 34.41 & 0.00 & 9.68 & 6.64 & 169.1651 & 217.7081 & 23.5360 & 74.730 & 24.28692 & 6.34507 & 108.332 \\
\hline Balrampur & 32.85 & 0.00 & 7.44 & 137.79 & 26.34 & 47.83 & 140.81 & 11.91 & 8.19 & 172.2408 & 247.1281 & 22.4662 & 0.000 & 29.74976 & 7.81757 & 110.7926 \\
\hline Barsoi & 29.10 & 0.00 & 8.12 & 149.03 & 25.58 & 44.07 & 0.00 & 12.98 & 8.86 & 186.2821 & 256.8634 & 23.2151 & 0.000 & 32.77487 & 8.48982 & 122.0257 \\
\hline Dandkhora & 23.20 & 92.97 & 4.90 & 108.27 & 19.68 & 34.97 & 106.78 & 7.84 & 5.49 & 135.332 & 209.4705 & 19.4172 & 72.967 & 19.11196 & 5.19507 & 81.26563 \\
\hline Falka & 24.20 & 92.97 & 5.78 & 147.10 & 19.25 & 35.97 & 108.27 & 9.25 & 6.37 & 183.8751 & 250.0701 & 24.1244 & 62.967 & 23.07079 & 6.07482 & 120.1 \\
\hline Hasangunj & 22.13 & 87.67 & 5.64 & 110.62 & 18.83 & 33.90 & 109.01 & 9.02 & 6.22 & 138.274 & 234.7717 & 19.1230 & 77.672 & 22.41599 & 5.92930 & 83.61923 \\
\hline Kadwa & 21.21 & 84.73 & 6.15 & 112.97 & 18.41 & 32.98 & 107.97 & 9.83 & 6.73 & 141.216 & 247.1281 & 22.3592 & 74.730 & 24.71625 & 6.44047 & 85.97283 \\
\hline Katihar & 20.30 & 82.20 & 6.95 & 135.33 & 17.99 & 32.07 & 106.78 & 11.12 & 7.54 & 169.1651 & 234.1833 & 17.6520 & 72.200 & 28.33721 & 7.24513 & 108.332 \\
\hline
\end{tabular}




\begin{tabular}{|c|c|c|c|c|c|c|c|c|c|c|c|c|c|c|c|c|}
\hline Korha & 19.38 & 79.43 & 5.95 & 150.04 & 17.57 & 31.15 & 106.42 & 9.52 & 6.54 & 187.5526 & 323.6201 & 24.1244 & 73.434 & 23.82829 & 6.24315 & 123.042 \\
\hline Kursela & 21.65 & 76.67 & 6.03 & 132.39 & 17.14 & 33.41 & 106.36 & 9.65 & 6.62 & 165.4875 & 264.7801 & 23.8302 & 66.669 & 24.1963 & 6.32493 & 105.39 \\
\hline Manihari & 21.68 & 73.90 & 6.51 & 138.27 & 19.60 & 33.44 & 106.30 & 10.41 & 7.10 & 172.8426 & 294.2001 & 22.0650 & 63.903 & 26.34592 & 6.80262 & 111.274 \\
\hline Mansahi & 20.93 & 71.14 & 6.35 & 140.04 & 20.44 & 32.70 & 106.24 & 10.16 & 6.94 & 175.0491 & 235.9485 & 21.1824 & 61.138 & 25.64016 & 6.64579 & 113.0392 \\
\hline Pranpur & 22.03 & 68.37 & 5.90 & 112.38 & 20.90 & 33.80 & 106.18 & 9.44 & 6.49 & 140.4805 & 235.2424 & 20.5940 & 58.372 & 23.62025 & 6.76660 & 85.38443 \\
\hline Sameli & 24.05 & 68.73 & 6.04 & 140.04 & 21.48 & 35.82 & 114.08 & 9.66 & 6.63 & 175.0491 & 289.4929 & 23.6537 & 58.725 & 24.22444 & 6.33118 & 113.0392 \\
\hline Total & 383.59 & 1056.37 & 104.44 & 2144.81 & 338.75 & 584.71 & 1596.22 & 167.11 & 114.50 & 2681.02 & 4087.28 & 358.2662 & 880.3655 & 419.7156 & 110.0416 & 1712.815 \\
\hline
\end{tabular}

Source: Authors' own calculations based on field survey (2016-2017)

Table 4: Block-wise yield of sequential crops in Katihar district

\begin{tabular}{|c|c|c|c|c|c|c|c|c|}
\hline Blocks & $\begin{array}{l}\text { Rice-rice- } \\
\text { vegetable }\end{array}$ & $\begin{array}{l}\text { Rice-maize- } \\
\text { rice }\end{array}$ & $\begin{array}{c}\text { Rice-maize- } \\
\text { maize }\end{array}$ & $\begin{array}{c}\text { Rice-maize- } \\
\text { jute }\end{array}$ & $\begin{array}{c}\text { Rice-pulse- } \\
\text { rice }\end{array}$ & $\begin{array}{c}\text { Rice-pulse- } \\
\text { jute }\end{array}$ & $\begin{array}{c}\text { Rice-pulse- } \\
\text { potato }\end{array}$ & $\begin{array}{c}\text { Maize-maize- } \\
\text { rice }\end{array}$ \\
\hline Azamnagar & 176.91 & 173.83 & 211.98 & 180.11 & 315.49 & 321.77 & 298.87 & 238.02 \\
\hline Amdabad & 169.46 & 179.34 & 153.13 & 189.54 & 336.35 & 346.54 & 319.43 & 153.78 \\
\hline Barari & 156.51 & 178.99 & 230.19 & 179.74 & 265.89 & 266.64 & 248.70 & 239.08 \\
\hline Balrampur & 164.11 & 53.32 & 30.85 & 60.60 & 300.45 & 307.73 & 285.80 & 22.47 \\
\hline Barsoi & 174.34 & 52.31 & 29.10 & 61.87 & 309.18 & 318.74 & 294.45 & 23.22 \\
\hline Dandkhora & 126.88 & 162.39 & 215.94 & 162.09 & 255.09 & 254.78 & 240.86 & 221.16 \\
\hline Falka & 168.43 & 156.60 & 195.44 & 155.54 & 298.40 & 297.34 & 280.35 & 215.36 \\
\hline Hasangunj & 127.87 & 153.26 & 211.81 & 156.55 & 279.03 & 282.32 & 265.83 & 215.80 \\
\hline Kadwa & 137.35 & 187.34 & 239.71 & 189.70 & 298.50 & 300.86 & 282.58 & 243.05 \\
\hline Katihar & 151.28 & 160.73 & 215.28 & 171.42 & 277.13 & 287.82 & 266.73 & 217.63 \\
\hline Korha & 174.55 & 187.92 & 237.23 & 187.63 & 375.12 & 374.83 & 357.24 & 243.98 \\
\hline Kursela & 155.57 & 166.54 & 209.38 & 166.90 & 314.96 & 315.32 & 297.45 & 216.86 \\
\hline Manihari & 159.02 & 174.04 & 215.88 & 178.32 & 341.94 & 346.22 & 326.68 & 222.27 \\
\hline Mansahi & 159.15 & 162.35 & 202.31 & 166.81 & 282.06 & 286.52 & 267.52 & 208.56 \\
\hline Pranpur & 128.01 & 168.81 & 206.59 & 171.84 & 277.87 & 280.89 & 264.04 & 215.15 \\
\hline Sameli & 160.74 & 175.79 & 210.86 & 176.36 & 337.20 & 337.77 & 319.87 & 220.46 \\
\hline
\end{tabular}

Source: Authors' own calculations based on Sentinel 2A data (2016-2017) 
Table 5: Block-wise cultivated land utilization index of identified crop sequence in Katihar district

\begin{tabular}{|c|c|c|c|c|c|c|c|c|}
\hline $\begin{array}{l}\text { Crop } \\
\text { Sequence }\end{array}$ & $\begin{array}{l}\text { Rice-rice- } \\
\text { vegetable }\end{array}$ & $\begin{array}{l}\text { Rice-maize- } \\
\text { rice }\end{array}$ & $\begin{array}{l}\text { Rice-maize- } \\
\text { maize }\end{array}$ & $\begin{array}{l}\text { Rice-maize- } \\
\text { jute }\end{array}$ & $\begin{array}{l}\text { Rice-pulse- } \\
\text { rice }\end{array}$ & $\begin{array}{l}\text { Rice-pulse- } \\
\text { jute }\end{array}$ & $\begin{array}{l}\text { Rice-pulse- } \\
\text { potato }\end{array}$ & $\begin{array}{l}\text { Maize-maize- } \\
\text { rice }\end{array}$ \\
\hline Azamnagar & 0.90 & 0.90 & 0.90 & 0.90 & 0.82 & 0.89 & 0.92 & 0.74 \\
\hline Amdabad & 0.90 & 0.90 & 0.90 & 0.90 & 0.82 & 0.89 & 0.92 & 0.74 \\
\hline Barari & 0.89 & 0.89 & 0.81 & 0.81 & 0.82 & 0.89 & 0.92 & 0.74 \\
\hline Balrampur & 0.92 & 0.92 & 0.82 & 0.82 & 0.92 & 0.92 & 0.82 & 0.82 \\
\hline Barsoi & 0.88 & 0.88 & 0.74 & 0.74 & 0.88 & 0.88 & 0.74 & 0.82 \\
\hline Dandkhora & 0.74 & 0.74 & 0.82 & 0.82 & 0.74 & 0.74 & 0.82 & 0.81 \\
\hline Falka & 0.74 & 0.74 & 0.81 & 0.81 & 0.74 & 0.74 & 0.81 & 0.81 \\
\hline Hasangunj & 0.74 & 0.74 & 0.74 & 0.74 & 0.74 & 0.74 & 0.74 & 0.82 \\
\hline Kadwa & 0.74 & 0.74 & 0.82 & 0.82 & 0.74 & 0.74 & 0.82 & 0.74 \\
\hline Katihar & 0.81 & 0.81 & 0.82 & 0.82 & 0.81 & 0.81 & 0.82 & 0.82 \\
\hline Korha & 0.74 & 0.74 & 0.74 & 0.74 & 0.74 & 0.74 & 0.74 & 0.81 \\
\hline Kursela & 0.74 & 0.74 & 0.89 & 0.89 & 0.74 & 0.74 & 0.89 & 0.74 \\
\hline Manihari & 0.90 & 0.90 & 0.92 & 0.92 & 0.90 & 0.90 & 0.92 & 0.82 \\
\hline Mansahi & 0.82 & 0.82 & 0.89 & 0.89 & 0.82 & 0.82 & 0.89 & 0.82 \\
\hline Pranpur & 0.82 & 0.82 & 0.63 & 0.63 & 0.82 & 0.82 & 0.63 & 0.74 \\
\hline Sameli & 0.82 & 0.82 & 0.67 & 0.67 & 0.82 & 0.82 & 0.89 & 0.74 \\
\hline Average & 0.82 & 0.82 & 0.81 & 0.81 & 0.80 & 0.82 & 0.83 & 0.78 \\
\hline
\end{tabular}

Source: Authors' own calculations based on Sentinel 2A data (2016-2017) 
Relationship of yield and CLUI were analyzed through the graphical representation. The analysis helped to understand the production and land utilization (Table 6). Relationship of crop sequence yield with NPK, bulk density and irrigation was also analyzed to suggest suitable crop sequence.

Table 6: Correlation between crop sequence yield and supporting land resources

\begin{tabular}{lcccc}
\hline \multirow{2}{*}{ Crop Sequence } & \multicolumn{3}{c}{ Coefficient of correlation $\left(\mathbf{R}^{\mathbf{2}}\right)$} & $\begin{array}{c}\text { Average } \\
\text { Production }(\mathbf{Q} / \mathbf{h a})\end{array}$ \\
\cline { 2 - 4 } & NPK & Bulk Density & Irrigation & 155.64 \\
Rice-rice-vegetable & 0.167 & 0.0159 & 0.0692 & 155.85 \\
Rice-maize-rice & 0.238 & 0.00003 & 0.0734 & 188.48 \\
Rice-maize-maize & 0.297 & 0.00007 & 0.092 & 259.69 \\
Rice-maize-jute & 0.0199 & 0.0003 & 0.0535 & 304.04 \\
Rice-pulse-rice & 0.2311 & 0.0469 & 0.2716 & 307.88 \\
Rice-pulse-jute & 0.0113 & 0.0431 & 0.2062 & 288.53 \\
Rice-pulse-potato & 0.0231 & 0.0521 & 0.2624 & 194.80 \\
Maize-maize-rice & 0.255 & 0.00002 & 0.0943 & \\
\hline
\end{tabular}

Source: Authors' own calculations based on field survey (2016-2017)

Rice- rice-vegetable sequence will be suitable in Korha and Falka blocks due to low CLUI and high yield (Figure 5). Rice-maize-rice was found suitable in Kadwa and Korha blocks (Figure 6). However, Balrampur and Barsoi have very low potential for this crop sequence. Rice-maizemaize, rice-maize-jute and maize-maize-rice were not suitable crop sequences except Korha block which has some potential in these sequences (Figure 7, 8 \& 9). Rice-maize-jute will be more beneficial in Pranpur and Sameli blocks (Figure 8). Korha block has more advantage for ricepulses-rice, rice-pulses-jute and rice-pulses-potato sequences (Figure 10, 11 \& 12). In terms of productivity and CLUI maize-maize-rice sequence will be beneficial for Azamnagar, Barari, Kadwa, Kursela, Pranpur and Sameli blocks (Figure 9).

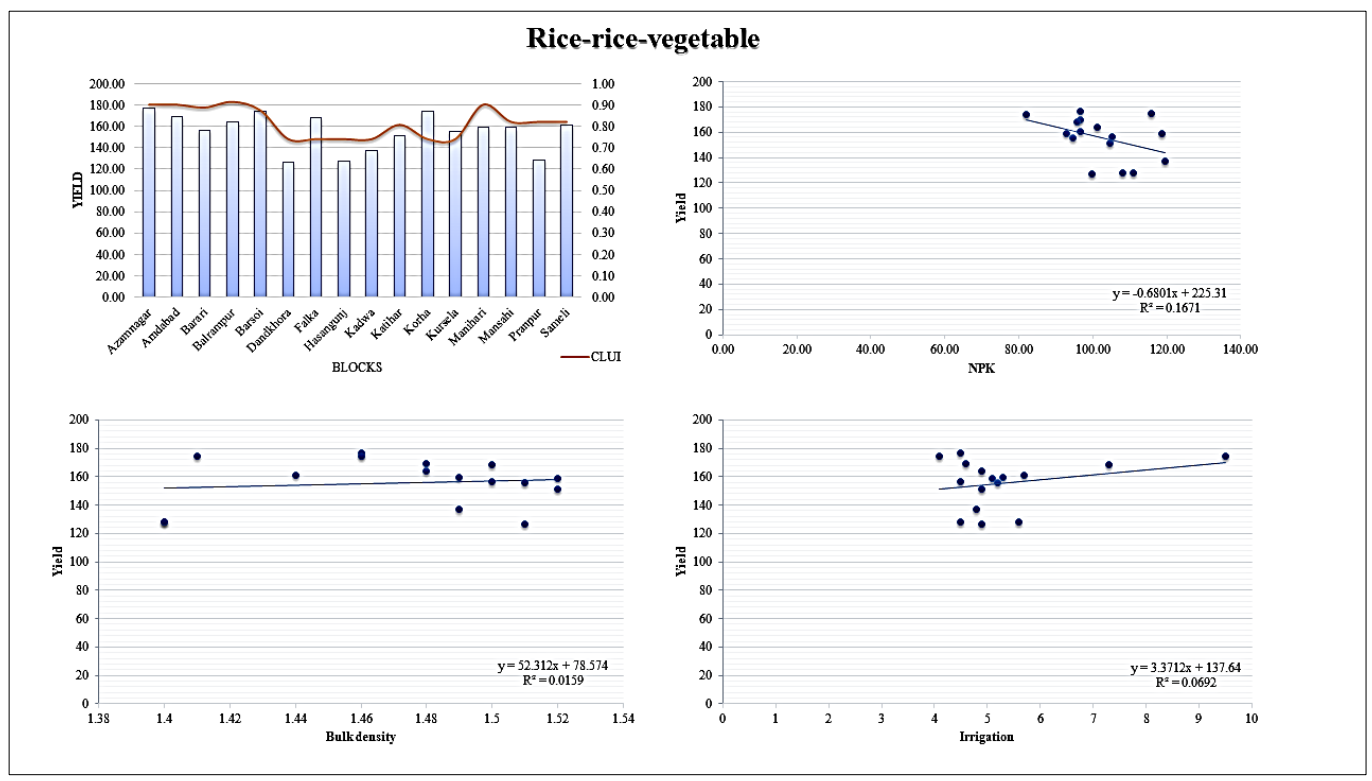

Figure 5: Relationship of yield with CLUI, NPK, bulk density and irrigation for rice-ricevegetable crop sequence 


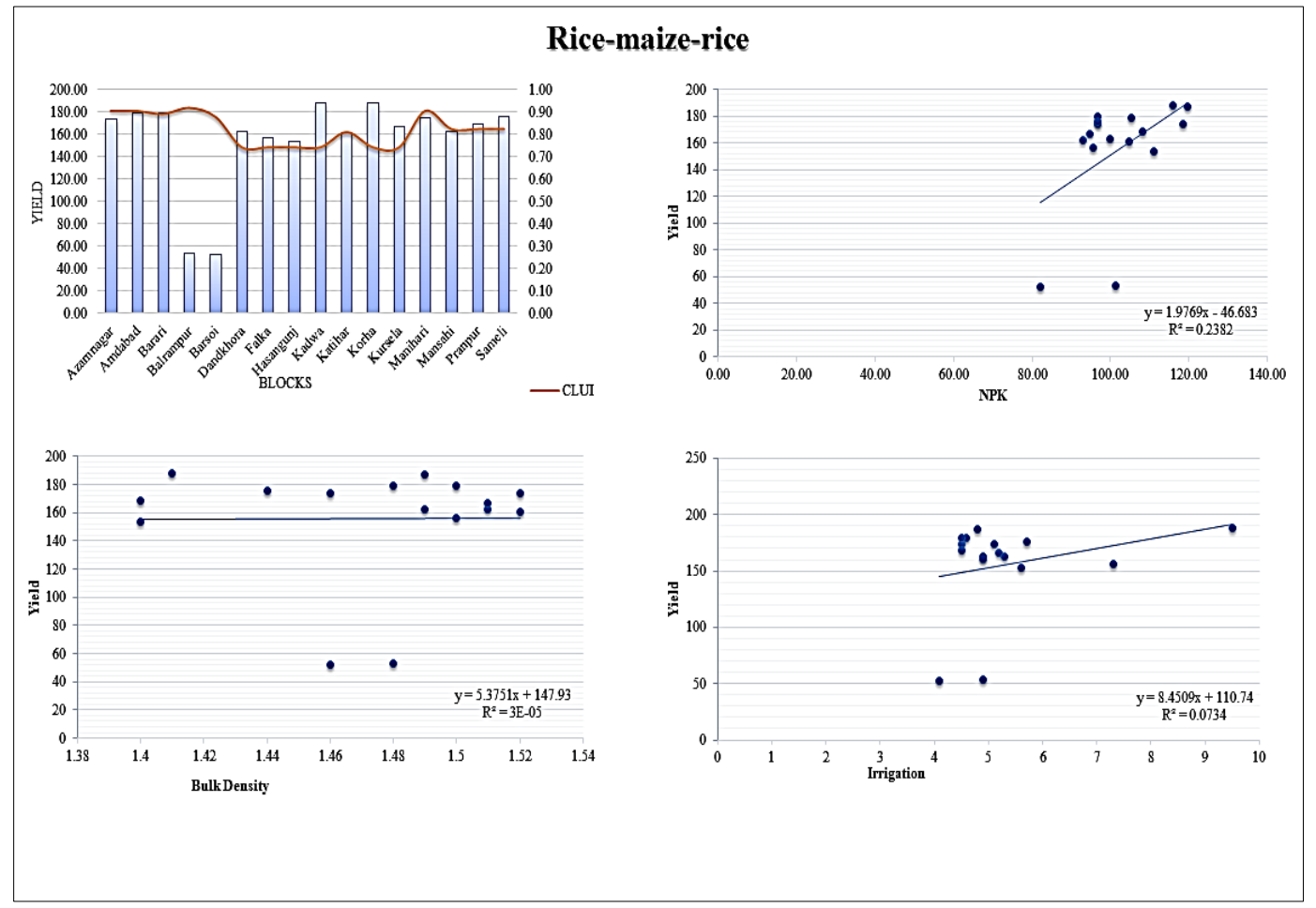

Figure 6: Relationship of yield with CLUI, NPK, bulk density and irrigation for rice-maizerice crop sequence

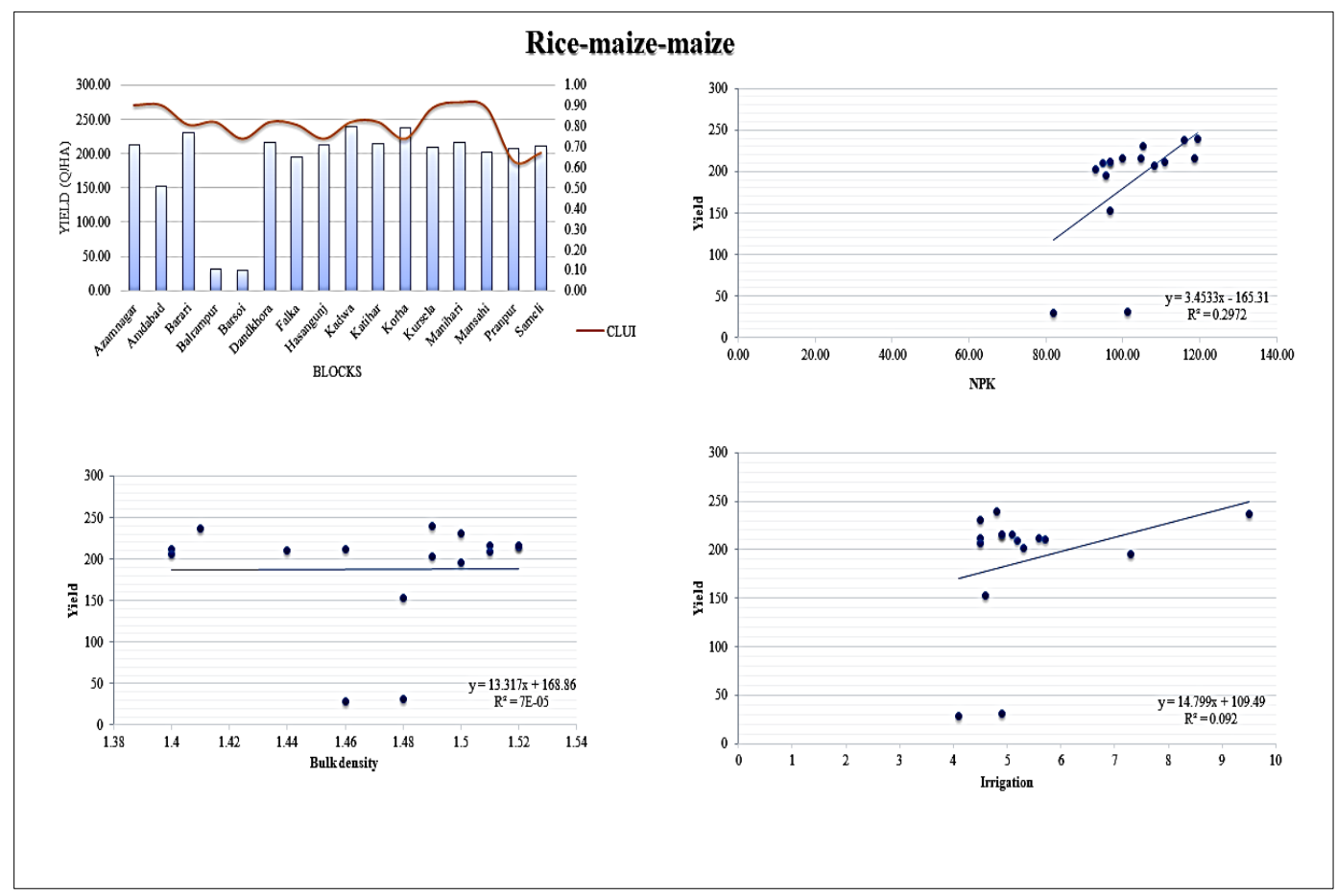

Figure 7: Relationship of yield with CLUI, NPK, bulk density and irrigation for rice-maizemaize crop sequence 


\section{Rice-maize-jute}
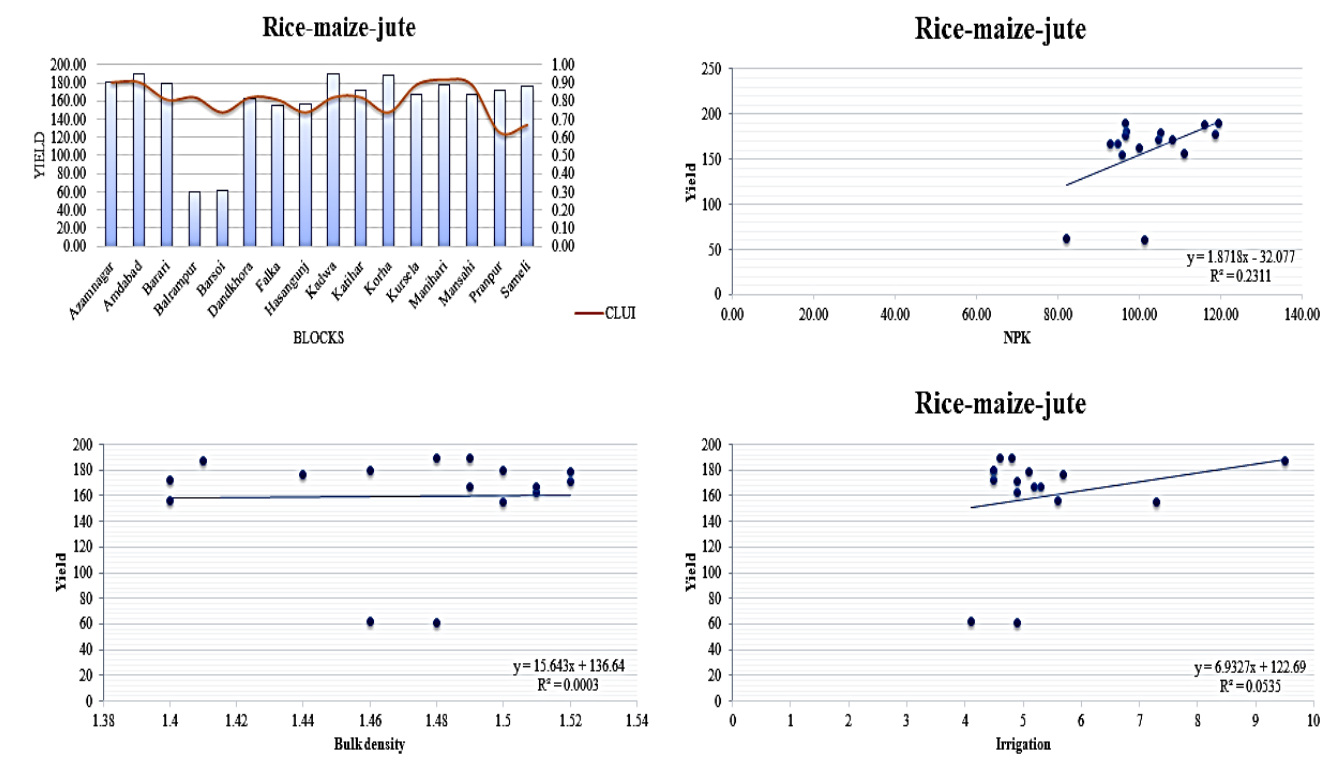

Figure 8: Relationship of yield with CLUI, NPK, bulk density and irrigation for rice-maizejute crop sequence

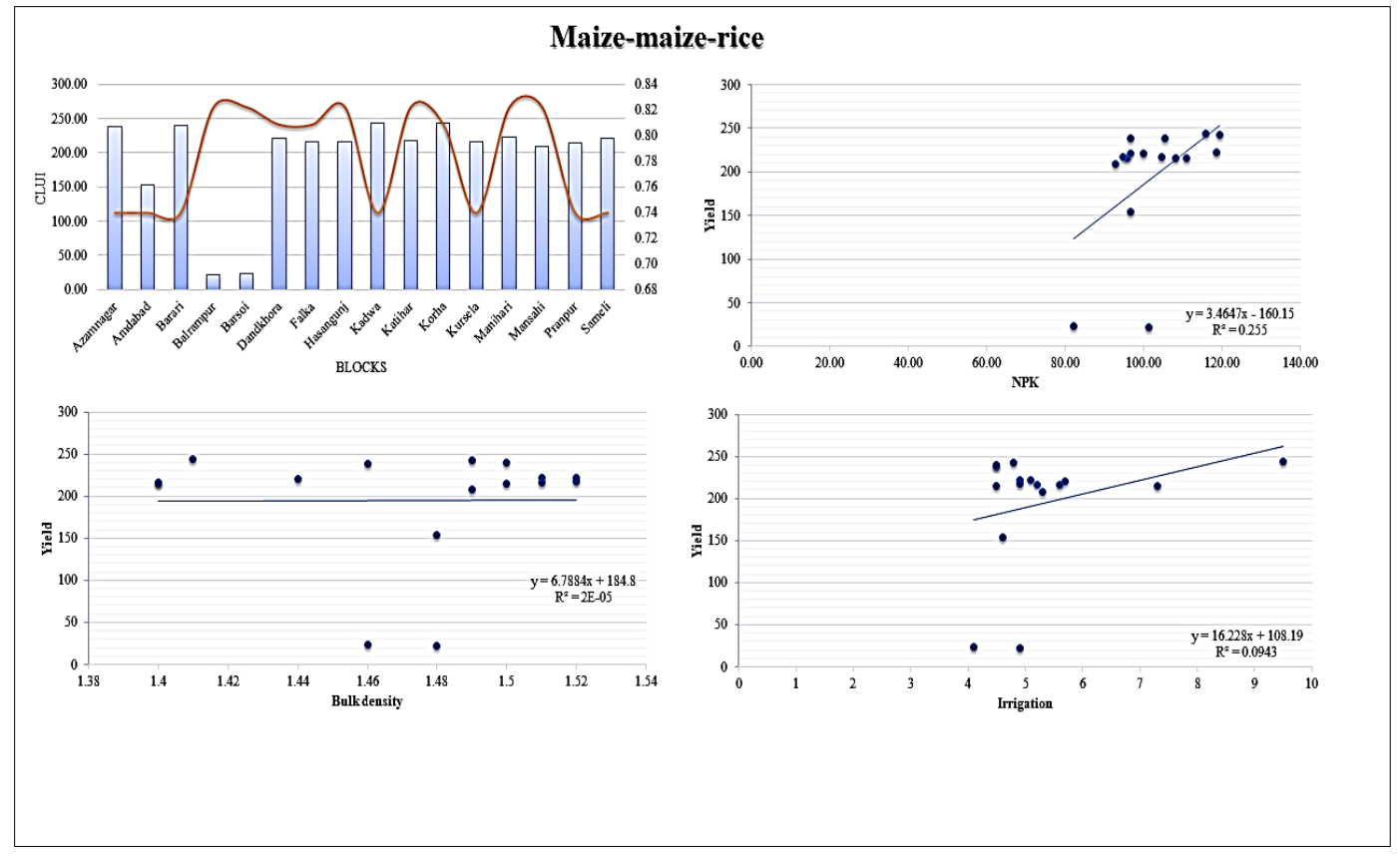

Figure 9: Relationship of yield with CLUI, NPK, bulk density and irrigation for maizemaize-rice crop sequence 


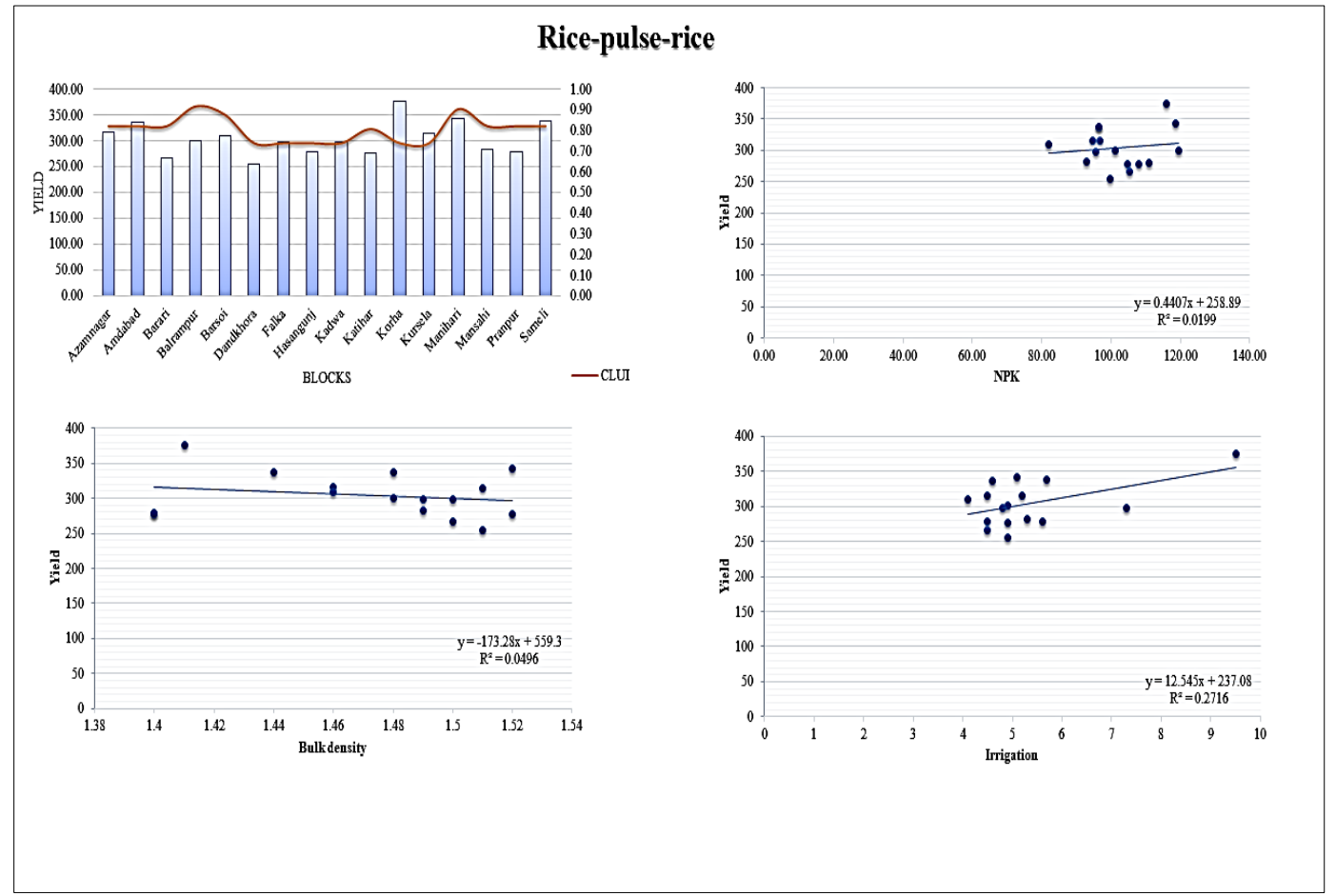

Figure 10: Relationship of yield with CLUI, NPK, bulk density and irrigation for maizepulse-rice crop sequence

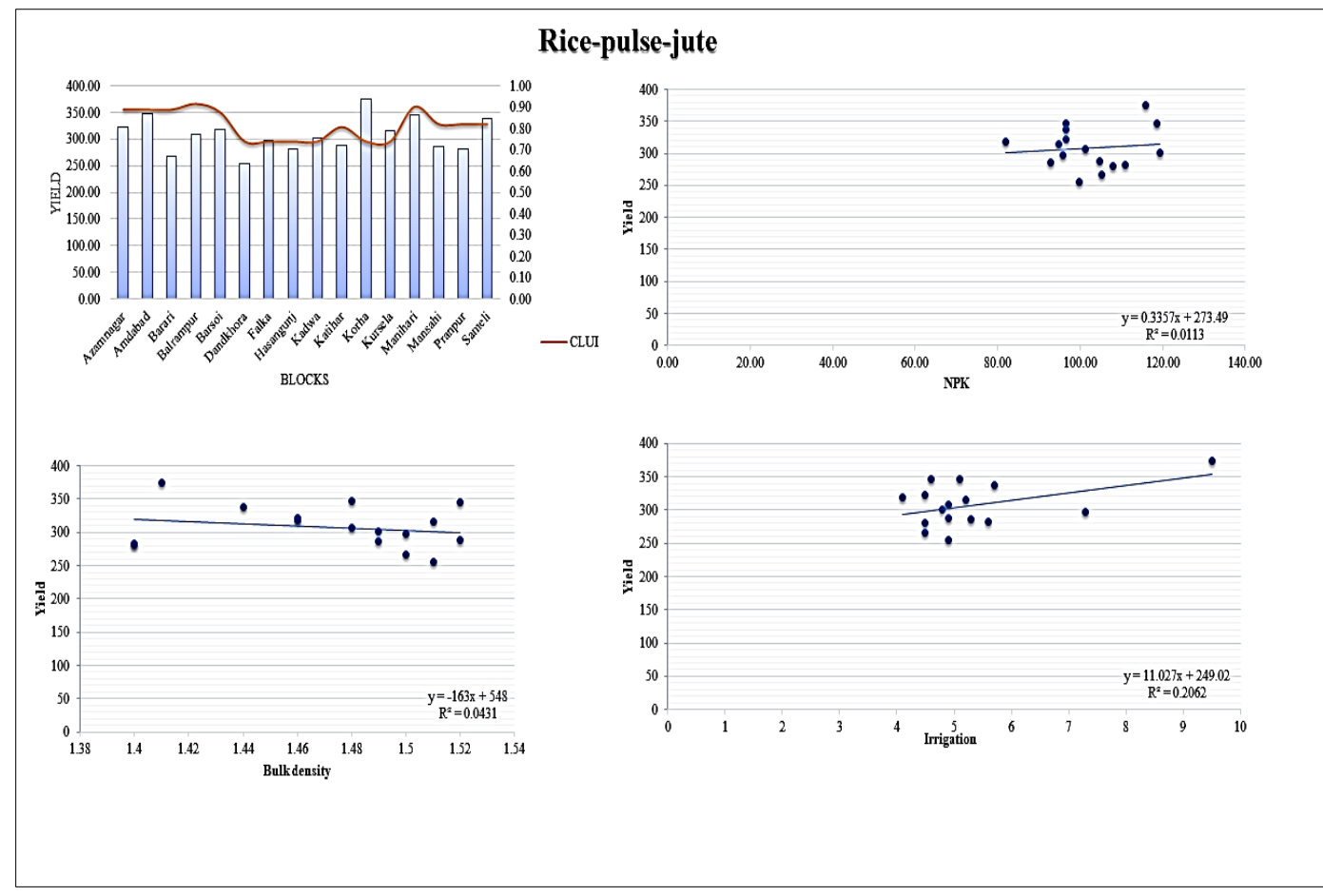

Figure 11: Relationship of yield with CLUI, NPK, bulk density and irrigation for rice-pulsejute crop sequence 


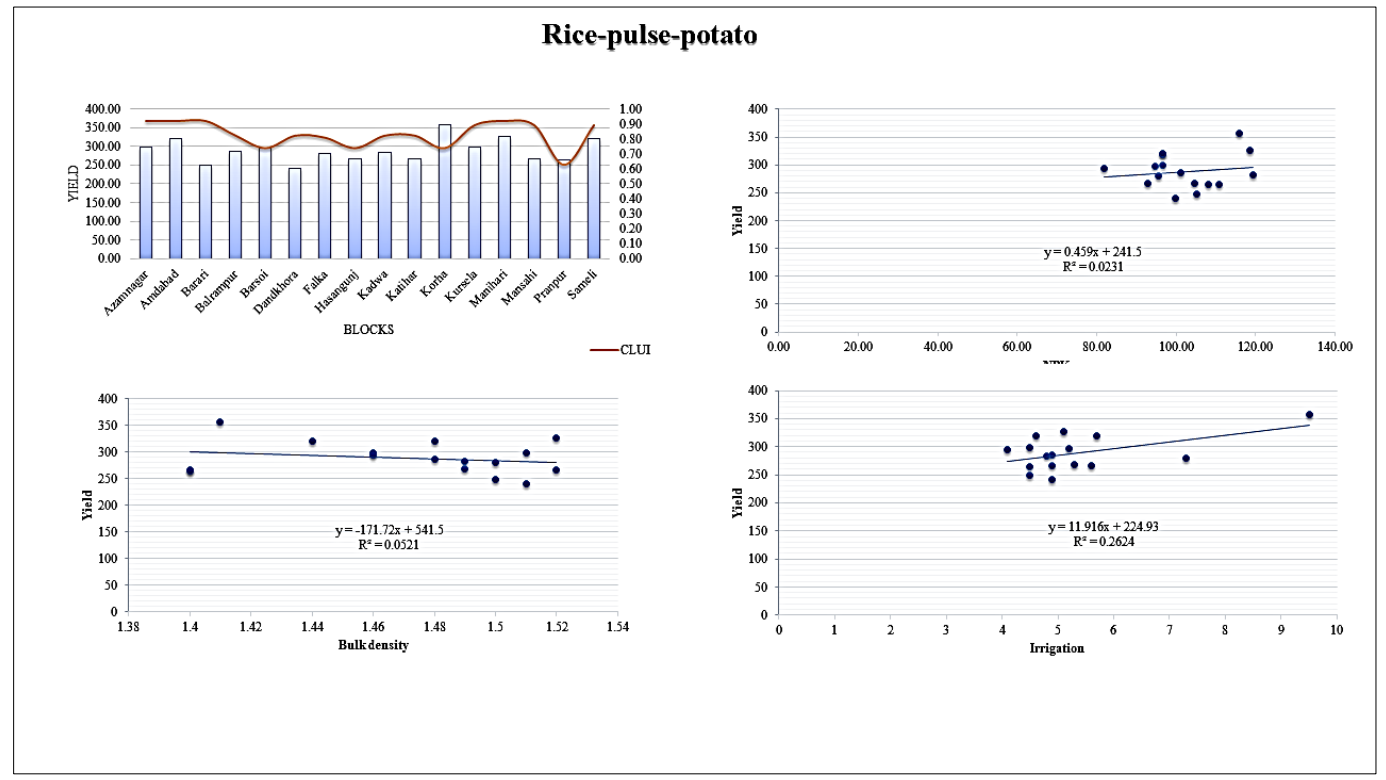

Figure 12: Relationship of yield with CLUI, NPK, bulk density and irrigation for rice-pulsepotato crop sequence

Korha has high potential for rice-rice-vegetable and rice-maize-rice. Rice-rice-vegetable is highly potential in Falka block. Kadwa block has high potential in rice-maize-rice sequence while Balrampur and Barsoi blocks have low potential in rice-maize-rice sequence. In rice-maize-maize crop sequence. Korha block has registered moderate potential in rice-maize-maize, rice-maize-jute, rice-pulse-rice, rice-pulse-rice, rice-pulse-jute and rice-pulse-potato sequences. Pranpur and Sameli blocks have high potential in rice-maize-maize. Azamnagar, Amdabad, Barari, Balrampur, Barsoi, Dandkhora, Falka, Hasangunj, Kadwa, Katihar, Kursela, Manihari, Mansahi and Pranpur blocks have registered potential in all sequence (Table 7). The scatter plots of NPK, bulk density and irrigation shows the relationship between yield and land resource potential.

The higher $\mathrm{R}^{2}$ value shows the increasing yield with increase in land resource potential. However, lower $\mathrm{R}^{2}$ value represents increasing yield with decreasing land resource potential. Therefore, in this study, the lower $\mathrm{R}^{2}$ value is most desirable as it represents the high yield production in marginally available land resources like NPK, bulk density and irrigation. Crop sequence with maximum average yield found in the rice - pulses - jute followed by rice - pulses - rice, rice - pulse - potato and rice- maize - jute. However, rice -maize- jute $\left(\mathrm{R}^{2}=0.02\right)$ is the most suitable sequence with low land resource potential followed by rice-pulse-jute $\left(\mathrm{R}^{2}=0.09\right)$, rice-pulse-potato $\left(\mathrm{R}^{2}\right.$ $=0.11)$ and rice-pulse-rice $\left(\mathrm{R}^{2}=0.18\right)$. Based on the analysis of the study, the ranking of crop sequences for maximum production in Katihar district are rice-pulse- jute followed by rice -maizejute, rice-pulse-rice and rice- pulse-potato. Jute is most suitable crop in flood inundated areas due to its resistance in flood. Rice is the prime food crop of the region and suitable for low laying areas. These crop sequence-based farming system will be more effective in the district due to their potential of maximum return with limited land resources. The production through these crop sequence may be increased from present condition with the use of farm machinery and fertilizers.

\section{CONCLUSION}

The study sought to determine a suitable crop sequence for sustainable agricultural development in flood-prone districts of Bihar in India. Sentinel 2A satellite data (2016-2017) was used to identify major land uses and cropping patterns for different agricultural seasons. A cultivated land 
utilization index was calculated to identify the period that land was under various crop sequences. A relationship was established between yield of crop sequences, NPK, bulk density, and irrigation. Rice-rice-vegetables, rice-maize-rice, rice-maize-maize, rice-maize-jute, rice-pulse-rice, ricepulse-jute, rice-pulse-potato, and maize-maize-rice were found to be the suitable crop sequences for this area under study. This study revealed rice-pulse-rice as the most suitable crop sequence, followed by rice-pulse-potato, and rice-maize-jute in terms of average maximum yield. With low resource potential, rice-maize-jute was found to be the most suitable sequence, followed by ricepulse-jute, rice-pulse-potato, and rice-pulse-rice. Balrampur and Barsoi blocks registered low potential in the rice-maize-rice sequence. In these blocks, effective farming techniques will play in important role in increasing the agricultural yield. In rice-maize-maize, rice-maize-jute, rice-pulserice, rice-pulse-rice, rice-pulse-jute, and rice-pulse-potato sequences, the Korha block registered moderate potential. However, the Azamnagar, Amdabad, Barari, Balrampur, Barsoi, Dandkhora, Falka, Hasangunj, Kadwa, Katihar, Kursela, Manihari, Mansahi and Pranpur blocks registered potential in all sequence. In these blocks, farm machinery is required to maximize the yield and achieve sustainability in agricultural productivity of the area under study. Efficiency in farm inputs, fertilizers, scrupulous irrigation, and maintenance of fallow cycles will help increase the overall productivity of the suitable crop sequences in the area under study.

Funding: This study received no specific financial support.
Competing Interests: The authors declared that they have no conflict of interests.
Contributors/Acknowledgement: The authors wish to thank the anonymous reviewers and editors, for
their constructive comments and suggestions for improving the overall quality of the manuscript.
Views and opinions expressed in this study are the views and opinions of the authors, Asian Journal of
Agriculture and Rural Development shall not be responsible or answerable for any loss, damage or liability
etc. caused in relation to/arising out of the use of the content.

\section{References}

Abrol, I. P., \& Sangar, S. (2006). Sustaining Indian agriculture-conservation agriculture the way forward. Current Science, 91(8), 1020-1025.

Agriculture Contingency Plan for District: Katihar (2012). http://www.crida.in/CP-
2012/statewiseplans/Bihar\%20(Pdf)/BI6-Katihar\%20-28.08.12.pdf. February, 2019.

Alemu, G. (2016). Characterization and analysis of farming system in chiro district, West Hararghe zone. Journal of Natural Sciences Research, 6(19), 45-51.

Amejo, A. G., Gebere, Y. M., Kassa, H., \& Tana, T. (2019). Characterization of smallholder mixed crop-livestock systems in integration with spatial information: in case Ethiopia. Cogent Food \& Agriculture, (just-accepted).

Bembridge, T. J. (1987). Crop farming system constraints in Transkei: Implications for research and extension. Development Southern Africa, 4(1), 67-89.

Census (2011). https://www.census2011.co.in/census/district/64-katihar.html. Accessed on $5^{\text {th }}$ February, 2019.

Chatterjee, S., Goswami, R., \& Bandopadhyay, P. (2015). Methodology of identification and characterization of farming systems in irrigated agriculture: case study in west Bengal State of India. Journal of Agricultural Science and Technology, 17(5), 1127-1140.

Choudhury, I., Chakraborty, M., Santra, S. C., \& Parihar, J. S. (2006). Characterization of agroecosystem based on land utilization indices using remote sensing and GIS. Journal of the Indian Society of Remote Sensing, 34(1), 23-37.

Das, P. (2006). Cropping pattern (agricultural and horticultural) in different zones, their average yields in comparison to national average/critical gaps/reasons identified and yield potential'. government of India, Ministry of Agriculture, Department of Agriculture and Cooperation (Ed), Status of Farm Mechanization in India, 33-47.

Dumanski, J., \& Pieri, C. (2000). Land quality indicators: research plan. Agriculture, Ecosystems \& Environment, 81(2), 93-102. 
Fan, C., Zheng, B., Myint, S. W., \& Aggarwal, R. (2014). Characterizing changes in cropping patterns using sequential Landsat imagery: an adaptive threshold approach and application to Phoenix, Arizona. International Journal of Remote Sensing, 35(20), 7263-7278.

FAO (2018). The state of agricultural commodity markets. Food and agriculture organization of the united nations Rome, 2018. http://www.fao.org/3/I9542EN/i9542en.pdf. Accessed on $5^{\text {th }}$ February, 2019.

FAO (2014). The state of food and agriculture 2014. Innovation in family farming. Rome. http://www.fao.org/3/a-i4040e.pdf. Accessed on $4^{\text {th }}$ February, 2019.

Food and Agriculture Organization of the United Nations (FAO). (2017). The future of food and agriculture. Trends and Challenges. Page no. 32-38.

Global Agricultural Productivity Index (2018). https://globalagriculturalproductivity.org/wpcontent/uploads/2018/10/Global-Agricultural-Productivity-Index_2018-GAP-Report.pdf. Accessed on $4^{\text {th }}$ February, 2019.

Hess, J. R., \& Hoskinson, R. L. (1996). Methods for characterization and analysis of spatial and temporal variability for researching and managing integrated farming systems. Precision Agriculture, (precisionagricu3), 641-650.

Iqbal, B. (2018). Indian agriculture: issues and challenges. Journal of Food Science and Toxicology, 2(1:4), 1-2.

Jamil, M., Ahmed, R., \& Sajjad, H. (2018a). Land suitability assessment for sugarcane cultivation in Bijnor district, India using geographic information system and fuzzy analytical hierarchy process. Geo Journal, 83(3), 595-611.

Jamil, M., Sahana, M., \& Sajjad, H. (2018b). Crop suitability analysis in the Bijnor District, UP, using geospatial tools and fuzzy analytical hierarchy process. Agricultural Research, 7(4), 506-522.

Kleijn, D., Kohler, F., Báldi, A., Batáry, P., Concepción, E. D., Clough, Y., \& Kovács, A. (2008). On the relationship between farmland biodiversity and land-use intensity in Europe. Proceedings of the Royal Society B: Biological Sciences, 276(1658), 903-909.

Liebisch, F., Küng, G., Damm, A., \& Walter, A. (2014, June). Characterization of crop vitality and resource use efficiency by means of combining imaging spectroscopy based plant traits. In Hyperspectral Image and Signal Processing: Evolution in Remote Sensing (WHISPERS), 2014 6th Workshop on (pp. 1-4). IEEE.

Overmars, K. P., Schulp, C. J., Alkemade, R., Verburg, P. H., Temme, A. J., Omtzigt, N., \& Schaminée, J. H. (2014). Developing a methodology for a species-based and spatially explicit indicator for biodiversity on agricultural land in the EU. Ecological Indicators, 37, 186-198.

Panigrahy, S., Manjunath, K. R., \& Ray, S. S. (2005). Deriving cropping system performance indices using remote sensing data and GIS. International Journal of Remote Sensing, 26(12), 2595-2606.

Rajbhandari, B. P. (2011). Relationships among rotational intensity, crop diversity index, land utilization index and yield efficiency in bio-intensive and conventional farming systems. Nepalese Journal of Agricultural Sciences, 9, 44-52.

Rana, S. S., \& Rana, M. C. (2011). Cropping system. Department of Agronomy, College of Agriculture, CSK Himachal Pradesh Krishi Vishvavidyalaya, Palampur, 80.

Reza, S. K., Nayak, D. C., Mukhopadhyay, S., Chattopadhyay, T., \& Singh, S. K. (2017). Characterizing spatial variability of soil properties in alluvial soils of India using geostatistics and geographical information system. Archives of Agronomy and Soil Science, 63(11), 1489-1498.

Ruiz-Martinez, I., Marraccini, E., Debolini, M., \& Bonari, E. (2015). Indicators of agricultural intensity and intensification: a review of the literature. Italian Journal of Agronomy, 10(2), 74-84.

Sajjad, H., \& Nasreen, I. (2016). Assessing farm-level agricultural sustainability using site-specific indicators and sustainable livelihood security index: Evidence from Vaishali district, India. Community Development, 47(5), 602-619. 
Sajjad, H., \& Prasad, S. (2014). Analyzing spatio-temporal pattern of crop diversification in Jalandhar district of Punjab, India. Asian Journal of Agriculture and Rural Development, 4(3), 242-256.

Sajjad, H., Nasreen, I., \& Ansari, S. A. (2014). Assessing spatiotemporal variation in agricultural sustainability using sustainable livelihood security index: Empirical illustration from Vaishali district of Bihar, India. Agroecology and Sustainable Food Systems, 38(1), 46-68.

Sheffield, K., \& Morse-McNabb, E. (2015). Using satellite imagery to asses trends in soil and crop productivity across landscapes. In IOP Conference Series: Earth and Environmental Science, 25(1), 012013. IOP Publishing.

Singh, H., Sharma, S. K., Dashora, L. N., Burark, S. S., \& Meena, G. L. (2013). Characterization and economics of farming systems in southern Rajasthan. Annals of Arid Zone, 52(1), $67-$ 70.

Timler, C., Michalscheck, M., Klapwijk, C., Mashingaidze, N., Ollenburger, M., Falconnier, G., \& Groot, J. (2014). Characterization of farming systems in Africa RISING intervention sites in Malawi. Tanzania, Ghana and Mali.

Van de Steeg, J. A., Verburg, P. H., Baltenweck, I., \& Staal, S. J. (2010). Characterization of the spatial distribution of farming systems in the Kenyan Highlands. Applied Geography, 30(2), 239-253

Zhang, W., \& Li, H. (2016). Characterizing and assessing the agricultural land use intensity of the beijing mountainous region. Sustainability, 8(11), 1-18. 